原 著

\title{
背景粘膜よりみた残胃癌の組織発生に関する病理組織学的検討 Pathological Studies on the Histogenesis of Carcinoma of the Gastric Remnant
}

\author{
和田了* \\ R yo WADA, M. D.
}

残胃に発生する癌の組織発生を明確にする目的で, 初回手術時の病変が良性疾患であり, 術後 10 年 以上経過している残胃癌25例および吻合部に，癌および潰瘍を認めない残胃対照例 25 例の計 50 例を， 病理組織学的に検索し次の結論を得た。

1. 残胃吻合部胃側の粘膜変化は, 腺窩上皮の過形成, 固有腺の萎縮, 胃底腺の偽幽門腺化生, 囊胞腺 および粘膜下侵入腺の出現を主体とし, 術後年数の長い B-II法群により顕著であった． 2. 腸上皮化 生は, 上記粘膜変化の顕著な B-II 法群の吻合部では極めてまれにしか認めなかったが， B- I 法群の 吻合部および吻合部から離れた残胃部（B-I法群およびB-II 法群）では，比較的高頻度に認められ た. 3. 残胃胃体部癌およびB-I 法吻合部癌は, 残胃という特殊な粘膜変化を背景として発生すると は考えられなかった。 4. 残胃縫合部癌例では過形成性腺窝上皮, 囊胞腺および粘膜下侵入腺が吻合 部癌例の場合程でないにしても高頻度にみられ，残胃という特殊な環境を背景に発生する可能性が示 唆されたが，今回の検索方法からはてれ以上の推察は難しかった．5.吻合部癌周囲に顕著にみられ た囊胞腺および粘膜下侵入腺の腺上皮には，本来胃粘膜上皮には存在しない lysozyme 強陽性細胞 の分布を比較的顕著汇認め, 乙のような露胞腺および粘膜下侵入腺の出現を背景とした lysozyme 強陽性細胞の出現と吻合部癌の存在は，因果関係があるものと考元られた。

索引用語 : 残胃癌, 吻合部癌, 吻合部胃炎, 腸上皮化生, lysozyme

Key Words : carcinoma of gastric remnant, stomal carcinoma, stomal gastritis, intestinal metaplasia, lysozyme

緒言

第38回胃癌研究会 (1982) の主題に「残胃の癌」 がとりあげられ，残胃の癌に対する関心は高い． 著者は, 残胃の癌の中でも発生母地としての残胃 の特殊性を限定する意味で, 初回手術時の病変が 良性疾患であり, 術後 10 年以上経過している残胃

* 順天堂大学医学部病理学第一講座

Department of Pathology (I), Juntendo University, School of Medicine

(Nov.18，1985受付）
に発生した癌のみを「残胃癌」と定義した ${ }^{1 \cdot 21}$.そ の定義に相当する自験残胃癌25例を研究対象とし, 残胃癌の背景粘膜および組織発生に関して, 病理 組織学的に検討した。

\section{材料と研究方法}

検索対象は，1977から1985年の 9 年間に順天堂 大学および関連病院にて, 外科的再切除および剖 検により得られた残胃吻合部癌14例と，吻合部以 外に発生した残胃癌11例の合計25例で, 何れも初 
表 1 a Stomal Carcinoma of the Gastric Remnant

\begin{tabular}{|c|c|c|c|c|c|c|c|}
\hline \multirow{2}{*}{$\begin{array}{l}\text { Case } \\
\text { Number }\end{array}$} & \multirow{2}{*}{ Age } & \multirow{2}{*}{ Sex } & \multicolumn{2}{|c|}{ Original Operation } & \multirow{2}{*}{$\begin{array}{l}\text { Time(y, } \\
\text { Interval }\end{array}$} & \multicolumn{2}{|c|}{ Carcinoma } \\
\hline & & & Indication & Method & & Gross appearance & Histological type \\
\hline 1 & 54 & $M$ & D-ul. & $B-1$ & 23 & II a & tub. 1 \\
\hline 2 & 54 & $M$ & D-ul. & B-II & 20 & Borr. 1 & pap \\
\hline 3 & 67 & $\mathrm{~F}$ & G-ul. & B-II & 25 & Borr. 3 & tub. 1 \\
\hline 4 & 53 & $M$ & G-ul. & B-II & 30 & Borr. 3 & tub. 2 \\
\hline 5 & 65 & $M$ & G-ul. & B-II & 32 & II a, II c, II a & tub. 1 , sig, tub. 1 \\
\hline 6 & 66 & $M$ & G-ul. & B-II & 28 & $\begin{array}{c}\text { Borr. } 1 \\
\text { (IIb:Anterior wall) }\end{array}$ & $\begin{array}{c}\text { pap } \\
\text { (tub. 1) }\end{array}$ \\
\hline 7 & 60 & $F$ & G-ul. & B-II & 11 & Borr. 3 & asq \\
\hline 8 & 62 & $F$ & G-ul. & B-II & 13 & II $c+$ II a & sig \\
\hline 9 & 43 & $M$ & G-ul. & B-II & 20 & Borr. 3 & por. \\
\hline 10 & 63 & $M$ & G-polyp & B-II & 22 & Borr. 3 & por \\
\hline 11 & 50 & $M$ & G-ul. & B-II & 24 & Borr. 3 & por \\
\hline 12 & 60 & $M$ & G-ul. & B-II & 29 & Borr. 4 & sig \\
\hline 13 & 77 & $M$ & D-ul. & B-II & 30 & Borr. 3 & sig \\
\hline 14 & 52 & $M$ & G-ul. & B-II & 41 & Borr. 3 & por \\
\hline
\end{tabular}

Case $1 \sim 6$ : 分化型癌, Case $7 \sim 14$ : 未分化型癌.

D-ul : Duodenal ulcer, G-ul : Gastric ulcer, G-polyp : Gastric polyp,

B-I : Billroth-I法, B- II : Billroth-II 法

表 1 b Non-stomal Gastric Remnant Carcinoma

\begin{tabular}{|c|c|c|c|c|c|c|c|c|}
\hline \multirow{2}{*}{$\begin{array}{l}\text { Case } \\
\text { Number }\end{array}$} & \multirow[b]{2}{*}{ Age } & \multirow{2}{*}{ Sex } & \multicolumn{2}{|c|}{ Original Operation } & \multirow{2}{*}{$\begin{array}{c}\text { Time } \\
\text { Interval } \\
(y)\end{array}$} & \multicolumn{2}{|c|}{ Carcinoma } & \multirow{2}{*}{ Site } \\
\hline & & & Indication & Method & & \begin{tabular}{c|c|} 
Gross \\
appearance \\
\end{tabular} & $\begin{array}{l}\text { Histological } \\
\text { type }\end{array}$ & \\
\hline 1 & 81 & $F$ & G-ul. & B- I & 11 & Borr. 3 & tub. 1 & Suture \\
\hline \multirow{2}{*}{2} & \multirow{2}{*}{71} & \multirow{2}{*}{$M$} & \multirow{2}{*}{ D-ul. } & \multirow{2}{*}{ B- I } & \multirow{2}{*}{11} & IIC & tub. 2 & Suture \\
\hline & & & & & & IIb & tub. 1 & Posterior wall \\
\hline 3 & 74 & $M$ & D-ul. & B- I & 20 & Borr. 2 & tub. 1 & Posterior wall \\
\hline 4 & 71 & $M$ & G-ul. & $B-I$ & 24 & Borr. 2 & tub. 2 & Suture \\
\hline 5 & 35 & $M$ & G-ul. & $B-I$ & 10 & IIb & sig & Anterior wall \\
\hline 6 & 60 & $M$ & G-ul. & $B-1$ & 13 & Borr. 3 & por & Suture \\
\hline 7 & 57 & $M$ & G-ul. & $B-I$ & 16 & Borr. 4 & por & Suture \\
\hline 8 & 51 & $M$ & G-ul. & $B-1$ & 20 & Borr.1+II $\mathrm{c}$ & sig & Suture \\
\hline 9 & 81 & $M$ & G-ul. & B-II & 10 & IIa & tub. 2 & Suture \\
\hline 10 & 47 & $M$ & D-ul. & B-II & 16 & IIa & pap & Anterior wall \\
\hline 11 & 63 & $M$ & D-ul. & B-II & 17 & Borr. 2 & tub. 1 & Posterior wall \\
\hline
\end{tabular}

Case $1 \sim 8$ : Billroth- I method, Case $9 \sim 11$ : Billroth-II method.

D-ul : Duodenal ulcer, G-ul : Gastric ulcer, G-polyp : Gastric polyp,

B-I : Billroth-I法, B-II : Billroth-II法 
表 2 Control cases of the Gastric Remnant

\begin{tabular}{|c|c|c|c|c|c|c|c|}
\hline \multicolumn{4}{|c|}{ Billroth-I method } & \multicolumn{4}{|c|}{ Billroth-II method } \\
\hline $\begin{array}{l}\text { Case } \\
\text { Number }\end{array}$ & $\begin{array}{c}\text { Time } \\
\text { Interval }\end{array}$ & Age $(y)$ & Sex & $\begin{array}{l}\text { Case } \\
\text { Number }\end{array}$ & $\begin{array}{r}\text { Time } \\
\text { Interval }\end{array}$ & Age $(y)$ & Sex \\
\hline 1 & $3 w$ & 63 & M & 1 & $8 \mathrm{~m}$ & 67 & M \\
\hline 2 & $1 \mathrm{~m}$ & 60 & $\mathrm{~F}$ & 2 & $2 y$ & 66 & M \\
\hline 3 & $2 \mathrm{~m}$ & 74 & $\mathrm{~F}$ & 3 & $2 y$ & 66 & M \\
\hline 4 & $1 \mathrm{y} 4 \mathrm{~m}$ & 72 & $\mathbf{M}$ & 4 & $5 y$ & 54 & $\mathbf{M}$ \\
\hline 5 & $2 y$ & 46 & $\mathbf{M}$ & 5 & $10 \mathrm{y}$ & 50 & M \\
\hline 6 & $3 y$ & 73 & M & 6 & $11 y$ & 57 & $\mathrm{~F}$ \\
\hline 7 & $5 y$ & 78 & M & 7 & $14 y$ & 41 & M \\
\hline 8 & $5 y$ & 78 & $\mathbf{M}$ & 8 & $18 y$ & 64 & $\mathbf{M}$ \\
\hline 9 & $7 \mathrm{y}$ & 66 & M & 9 & $20 \mathrm{y}$ & 54 & M \\
\hline 10 & $10 y$ & 65 & $\mathbf{M}$ & 10 & $28 \mathrm{y}$ & 65 & $\mathbf{M}$ \\
\hline 11 & $15 y$ & 76 & $\mathbf{M}$ & 11 & $40 y$ & 82 & $\mathbf{M}$ \\
\hline 12 & $17 y$ & 70 & $\mathrm{~F}$ & & & & \\
\hline 13 & $28 \mathrm{y}$ & 90 & $\mathbf{M}$ & & & & \\
\hline 14 & $29 y$ & 71 & $\mathbf{M}$ & & & & \\
\hline
\end{tabular}

回手術時の病変が良性疾患で, 術後 10 年以上経過 した後残胃癌が発見された症例である.表-1 aは吻 合部癌14例であり, 分化型癌と未分化型癌に分け それぞれ術後年数順に並べた.表-1 b は吻合部癌 以外の残胃癌11例であり，まず術法で分け，次に それぞれを, 分化型癌・未分化型癌に分け術後年 数順に並べた.なお組織型は, 胃癌取り扱い規約 31 に準じたが, papillary adenocarcinoma (pap), tubular adenocarcinoma well differentiated type (tub. 1) および moderately differentiated type (tub. 2) は分化型癌に入れ, poorly differentiated adenocarcinoma (por), signet-ring cell carcinoma（sig）は未分化型癌とした。また， 剖検により得られた吻合部に癌巣および潰瘍を認 めない残胃例25例（表-2）を対照群とした。残胃 癌群と対照群は年齢的に有意な差がない。これら 全例のうち23例は小弯に平行に全割し, 残りの 27 例は前後壁・小弯の各 3 本を最低切り出し, 切片 を作成した後パラフィン・ブロックより, H.E.染 色, 各種粘液染色（PAS 染色, Con-A（III）染色, HID-AB 染色）および PAP 法により免疫組織 学的染色 (1ysozyme, secretory component: SC) も施行した。また特に lysozyme 染色に対する検 討をするため, 胎览期 5 例 $(9,10,11,41,41$
週)，新生児 - 乳児期 6 例（ 0 日： 4 例， 3 月 $\& 9$ 月： 1 例ずつ), 幼児・学童期 5 例 $(2,2.5,6,8$, 11歳）のそれぞれの, 胃・小腸・大腸・胆囊とさ らに成人胃 10 例, 多発性胃粘膜下囊腫 4 例を検索 に加えた。

\section{結果}

\section{1. 残胃癌自験例の概要}

\section{A）占拠部位}

残胃癌を癌巣の主なる占拠部より, 吻合部癌と その他の部位の残胃癌の 2 つに分類し, さらに後 者を, 縫合部癌・胃体部癌・噴門部癌の 3 つに亜 分類した. 残胃癌 25 例 29 病巣のうち, 吻合部癌 14 例16病巣 $(55 \%)$, 縫合部癌 7 病巣 $(24 \%)$, 胃体 部癌 6 病巣 $(21 \%)$, 噴門部癌 0 病巣であった。ま た, 多発性残胃癌は 3 例あり表- $1 \mathrm{a}$ の症例 $5^{4}$ 'は, 同一吻合部の前後壁に分化型癌, 小弯上に未分化 型癌がおのおの別個に衝突性に存在した 3 重癌で あった。表-1 aの症例 6 には, 吻合部癌（分化型 癌）と胃体部癌（分化型癌）がそれぞれ 1 病巣ず つ認められ, 表-1 bの症例 2 には, 縫合部癌（分化 型癌）と胃体部癌（分化型癌）がそれぞれ個別に 認められるものであった。

\section{B）手術術式と残胃癌との関係}

手術術式は, 残胃癌25例中, B- I 法群：9例, B-II 法群：16例でB-II法が多かった.吻合部癌で は，14例中13例（93\%）が Braun 吻合術を付加 していない B-II 法であった。その他の残胃癌では, B- I 法群 : 8 例 ( 9 病巣), B-II法群 : 4 例 ( 4 病巣) でB-I 法群に多かった。

C) 性別・年齢

男21例 女 4 例で, 吻合部癌群（男11例 女 4 例）およびその他の残胃癌群（男10例 女 1 例） のいずれにおいても男性に多かった。残胃癌全体 の平均年歯令は60.7歳（35～81歳）, 吻合部癌群： 平均59歳 (分化型癌 : 59.8 歳, 未分化型癌 : 58 . 3歳), その他の残胃癌群 : 平均63.1歳 (分化型癌

: 69.7歳, 未分化型癌： 50.7歳).

D) 術後年数 


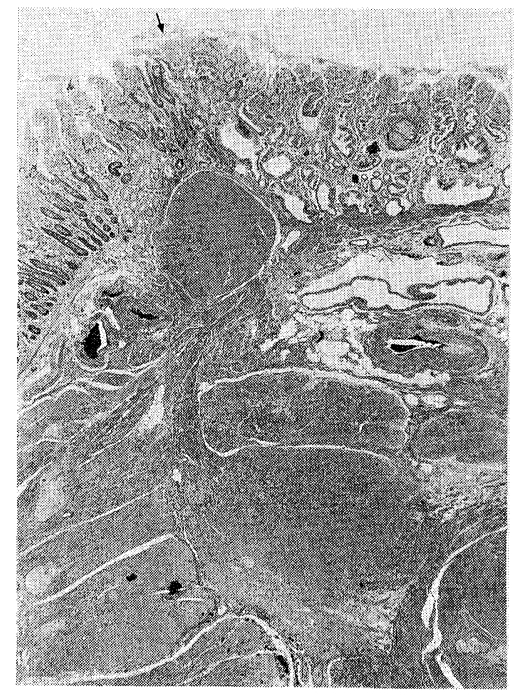

図 1 吻合部（Billroth- II 法）(矢印)

右半胃粘膜部门囊胞腺, 粘膜下侵入腺をみる

(H.E. $\times 20)$

全体では平均20.6年（10４1年), B- I 法群: 16 . 4 年（10～ 24 年), B- II 法群：21.8年（10４1年）, 吻合部癌群: 24.9 年 $(11 \sim 41$ 年), その他の残胃癌 群: 16.3年 $(10 \sim 24$ 年).

E) 残胃癌の肉眼および組織所見

全体では，29病巣のうち早期癌は11病巣（II a: 5, II b: 3, II c: 2, II c + II a: 1), 進行癌は 18 病 巣 (Borr.1: 3, Borr.2: 3, Borr.3: 10, Borr.4:

2) であった.吻合部癌群では16病巣のうち早期癌 は5病巣, 進行癌は11病巣であったが, その他の残 胃癌群では13病巣のうち早期癌は6病巣, 進行癌 は7病巣であった。これを佐野 ${ }^{51}$ の分類にならって, 残胃癌の肉眼型を隆起型（II bを含む）と潰瘍型 に分類すると, 吻合部癌群では隆起型5病巣（全 て分化型癌), 潰瘍型11病巣 (分化型癌: 2 , 未分 化型癌: 9), その他の残胃癌群では隆起型6病宩 (分化型癌： 4 , 未分化型癌：2), 潰瘍型7病巣（分 化型癌：5, 未分化型癌：2）であった。組織型は 全体では, 分化型腺癌：15病巣，未分化型腺癌：1 3病巣, 未分化型腺癌を有す腺扁平上皮癌: 1 病巣 であった.また吻合部癌群では, 分化型腺癌: 7 病
巣, 未分化型腺癌: 9 病巣であったが，その他の 残胃癌群では, 分化型腺癌: 9 病巣, 未分化型腺 癌: 4 病巣であった。

2. 残胃吻合部胃側の粘膜変化

\section{A）対照群吻合部胃粘膜変化}

残胃吻合部の粘膜変化を検索するために, 残胃 対照群25例 [B- I 法対照群: 14例（術後10年以 上： 5 例), B- II 法対照群: 11例（術後 10 年以上: 7 例)]および吻合部に, 癌・潰瘍を認めないその 他の残胃癌群11例（B- I 法群：8例, B- II 法: 3 例）の計36例を対照とし, B-I 法あるいは B- II 法の手術の行われた 2 群に分けて検索した。すな わち, B- I 法対照群14例と吻合部に, 癌・潰瘍を 認めない B- I 法残胃癌群 8 例の合計 22 例を B- I C 群とした。同様に, B-II 法対照群11例とB- II 法残胃癌群 3 例の合計14例を B- II-C 群とした。 なお, B-II-C 群のうち2 例は, Braun 吻合を付 加された症例である.

これらの対照群について, 以下の点—1）腺窝 上皮の過形成性変化 2) 固有腺の萎縮および胃 底腺の偽幽門腺化生をはじめとする慢性胃炎の程 度 3）腸上皮化生 4) 固有腺の囊胞状拡張（囊 胞腺, 顕微鏡下で囊胞腺之認識できる腺管の断面 における外周は, 胃底腺外周の約 2 倍以上, $200 \mu$ 以上に相当し，乙れらを囊胞腺とした） 5）固 有腺の粘膜下組織への侵入（粘膜下侵入腺） 6）粘膜固有層間質の豊富な毛細血管 —をそ れぞれ組織学的に, 術法および部位別で比較し た。

1): 腺窝上皮の過形成性変化は（図-1）, 吻合部 直上に顕著で, 口側に向ってしだいに粘膜の厚さ （粘膜筋板から粘膜上皮最表層までの高さ）は軽 減していた。乙の粘膜の厚さは B-II-C 群には目 立ったが, B-I-C 群では軽微であった。また,一 般に前後壁・大小弯においての部位による有意な 差はなかった，粘膜表層の腺管は，ややくびれを 呈し軽度の細胞異型を示していた。

2）および 3): 平福 ${ }^{6}$ の慢性胃炎の分類を応用 して, 吻合部の固有腺の萎縮, 粘膜筋板の肥厚お よび腸上皮化生の拡がりの程度を 5 段階（ $0 ， 0.5$, 
表 3 各群の吻合部における慢性胃炎の程度

\begin{tabular}{|c|c|c|c|c|c|}
\hline & 固有腺の菱縮 & & 粘膜筋板の肥厚 & 腸上皮化生の & 分布程度 \\
\hline $\begin{array}{c}B-1-C \text { 群(17 例) } \\
B-1-C \text { 群(10 例) } \\
\text { (術後10年以上) }\end{array}$ & {$\left[\begin{array}{r}0.56 \pm 0.35 \\
2.60 \pm 0.39\end{array}\right]$} & 1 & {$\left[\begin{array}{r}0.59 \pm 0.32 \\
0.70 \pm 0.26\end{array}\right] 3$} & 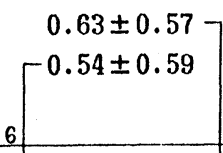 & 5 \\
\hline $\begin{array}{r}\text { B-II -C群(10 例 }) \\
\text { B- II -C群 }(8 \text { 例 }) \\
\text { (術後 10年以上 })\end{array}$ & {$\left[\begin{array}{l}1.00 \pm 0 \\
1.00 \pm 0\end{array}\right]$} & & {$\left[\begin{array}{l}0.85 \pm 0.24 \\
0.81 \pm 0.26\end{array}\right.$} & {$\left[\begin{array}{l}0.08 \pm 0.03 \\
0.00 \pm 0\end{array}\right.$} & \\
\hline
\end{tabular}

$1: P<0.001,2,3: P<0.05,5,6: P<0.01,4:$ 差なし

B- II -C 群の吻合部は, B- I -C 群の場合に比し, 固有腺の萎縮, 粘膜筋板の肥厚が目立ったが, 逆に腸上皮化生 は B-II-C 群では, ほとんどみられなかった。

1，1.5，2）で表現し，それれらを表-3の如く, 統 計処理した結果, 固有腺の萎縮の程度は B- II -C 群で B- I -C 群より著明にみられ, 術後 10 年以上 の群においても同様であった. 粘膜筋板の肥厚の 程度も B-II-C 群に有意に厚かった。 また腸上皮 化生は, 吻合部胃側の $38 \%$ （12例 $/ 32$ 例）に認め られたが, B-I-C 群では58\%（11例／19例）と より高頻度にみられた。一方，B-II-C 群では $8 \%$ （1例 $/ 13$ 例）と低く, 後述の吻合部癌群を含め てもわずか $4 \%$ 弱（1例 $/ 26$ 例）であった。 そし て腸上皮化生の出現分布は, ほとんどが小弯（縫 合部）中心性であった. また, 出現した腸上皮化 生は, 大部分が完全型であったが, 不完全型の場 合もあった。

4）および 5): 囊胞腺および粘膜下侵入腺の出 現は, 吻合部粘膜変化の中でも最も特徵的な所見 と考えられているので, 別項で詳細に述べる.

6): 粘膜固有層間質では, 軽度わら中等度の炎 症性細胞浸潤と比較的豊富な毛細血管の存在をみ た. 毛細血管の存在は, B-II-C 群の吻合部に比較 的数多く認められた（表 4）が, 術法における有 意な差は認められなかった。

B）吻合部癌群の吻合部胃粘膜変化

吻合部癌14例16病巣 (B- I 法: 1 例 1 病巣, Braun 吻合付加していないB-II 法: 13例15病巣） 中11病巣は進行癌で, 5 病巣は吻合部全体に癌巣
表 4 各群に吻合部粘膜固有層内の毛細血管の密度と術 後年数

\begin{tabular}{|c|c|c|c|c|c|c|c|c|}
\hline$(H)$ & 1 & 1 & & & 1 & 4 & & 1 \\
\hline$(+)$ & 5 & 3 & 2 & & 2 & 2 & 1 & \\
\hline$( \pm)$ & $\sum_{\text {cases }}$ & 1 & 1 & & & & & \\
\hline 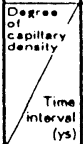 & ${ }_{11}^{0}$ & $\int_{20}^{11}$ & $\int_{30}^{21}$ & 31 & $\int_{10}^{0}$ & $\int_{20}^{11}$ & $\int_{30}^{21}$ & $\int^{31}$ \\
\hline & \multicolumn{4}{|c|}{ B-I method } & \multicolumn{4}{|c|}{ B-II method } \\
\hline
\end{tabular}

の進展を認め, 8 病巣は吻合部腸側へも数 $m m$ か ら $3 \mathrm{~cm}$ にわたり進展していた. 従って, 必ずしも 吻合部全体の粘膜変化を検索しえなかった。しか しながら，B- II 法吻合部癌群の癌浸潤のない吻 合部胃側を検索すると，腺窩上皮の過形成，固有 腺の萎縮および胃底腺の偽幽門腺化生, 囊胞腺お よび粘膜下侵入腺の出現等の粘膜変化か顕著であっ た. 固有腺の萎縮程度は 5 段階に分けて比較する と, 術後 10 年以上の B- II -C 群 $(1.00 \pm 0.00)$ と 比較しても, 吻合部癌群 $(1.25 \pm 0.27)$ 亿有意に 目立ち $(\mathrm{P}<0.05)$, また後述の如く囊胞腺および 
図 $2 \mathrm{a}$ 各群における囊胞腺の出現数と吻合部からの分 布範囲の関係 (口側)
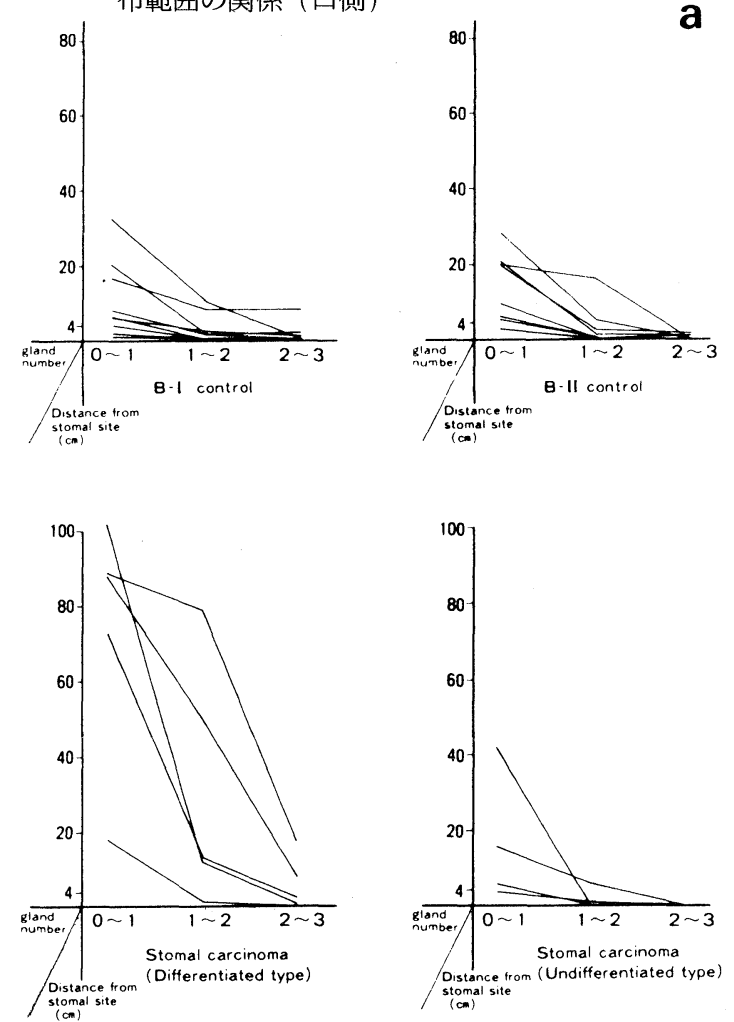

縦軸：腺管数

横軸：吻合部からの距離（口側） $(\mathrm{cm})$
図 $2 \mathrm{~b}$ 各群における粘膜下侵入腺の出現数と吻合部か らの分布の関係 (口側)
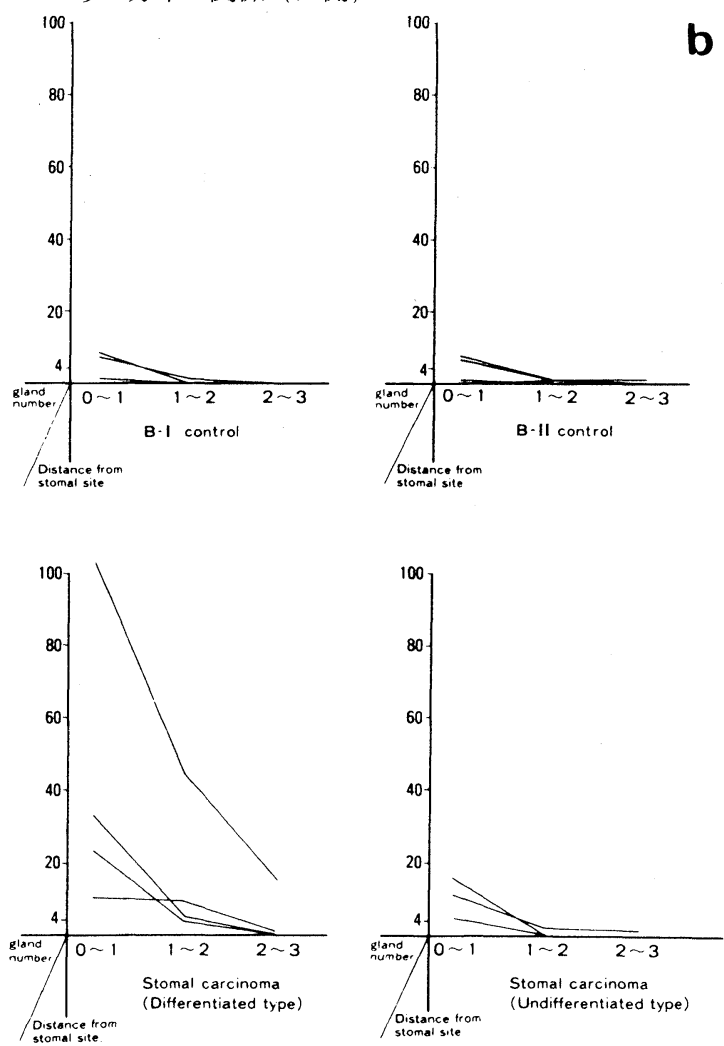

縦軸：腺管数

横軸：吻合部からの距離（口側） $(\mathrm{cm})$

（14例）および吻合部癌群（14例）の100\%であり, 粘膜下侵入腺の場合は B- I -C 群の $14 \%$ （3 例 $/$ 22例)，B- II-C 群の57\%（8 例 $/ 14$ 例), 吻合部癌 群の $82 \%$ （9例 $/ 11$ 例）であった。囊胞腺および 粘膜下侵入腺は, 吻合部より口側 $3 \mathrm{~cm}$ 考詳細に検 索すると, 吻合部から口側 $2 \mathrm{~cm}$ 以内の領域にその ほとんどが分布し（図-2a，b），また同領域での 平均囊胞腺出現数 (全囊胞腺数/吻合部全割切片 数）を統計処理した結果（表-5）, 術後 10 年以上の 場合においても， B- I -C 群よりも B- II-C 群に 多く, しかも B-II-C 群においては, 術後年数と ほほ相関して増加する傾向にあった（図-3）. 同様 に算出した平均粘膜下侵入腺出現数も, B- I -C群
囊胞腺の出現力漂本上 1 力所以上みられた症例 は, B- I-C 群の59\%（13例／22例)，B- II-C 群 
表 5 各群の吻合部から $2 \mathrm{~cm}$ 以内における囊胞腺, 粘膜下侵入腺の出現数および囊胞腺の周長総和

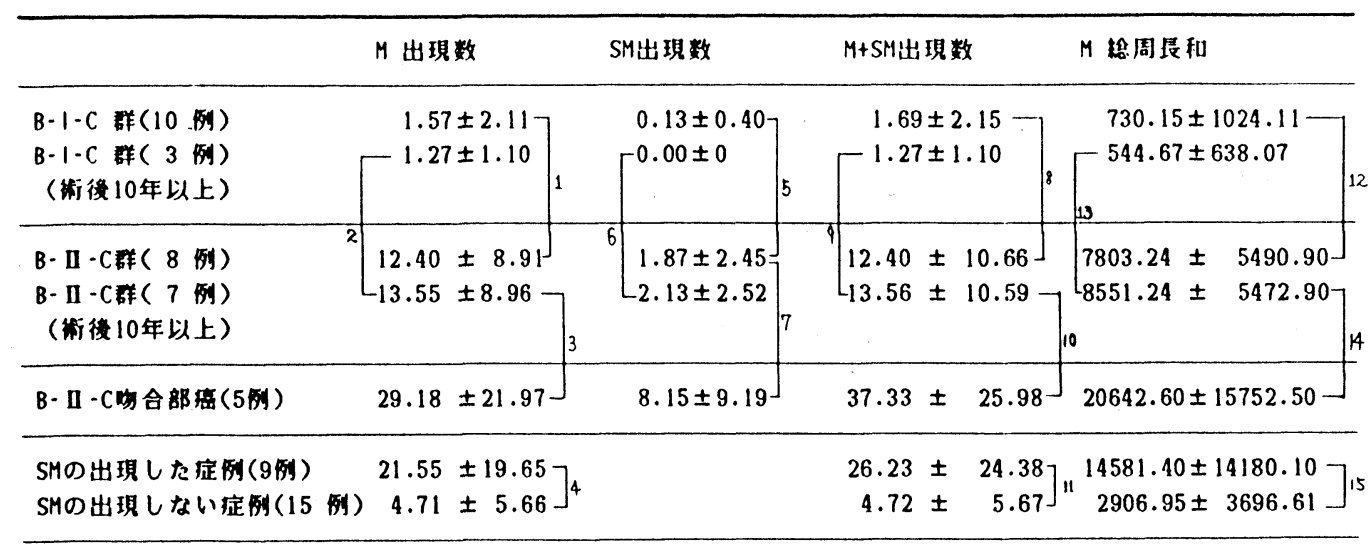

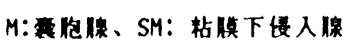

$12<0.01 、 1,2,4,8,9,11,13,15: P<0.05 、 5,6: P<0.1 、 3,7,10,14:$ 差なし

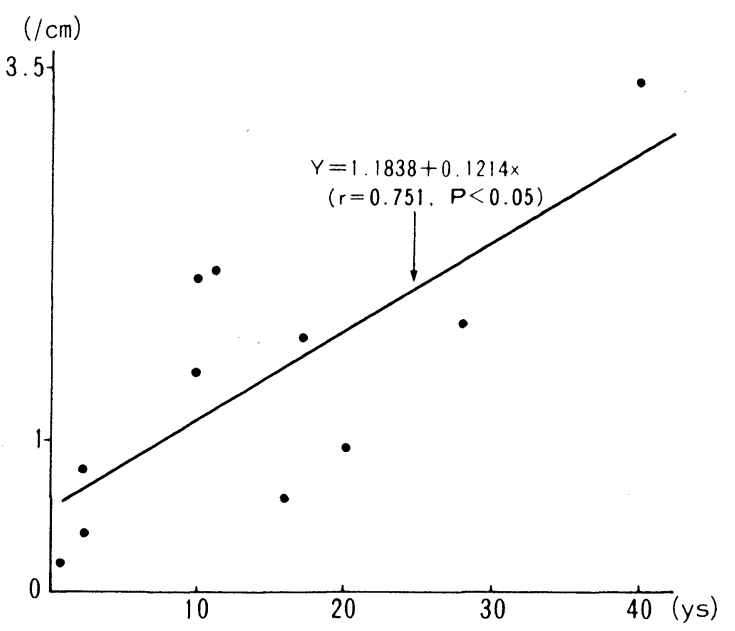

図 3 囊胞腺の出現数 (縦軸) と術後年数 (横軸) の関係

よりも B-II-C 群に多かった。また，粘膜下侵入 腺は囊胞腺が顕著に出現する際に出現する率が高 かった．両者の出現分布は吻合部の前後壁におけ る部位的な差はなかった。

そこで, 囊胞腺および粘膜下侵入腺の関係を明 確にすべく, 連続切片標本を作製して検索した。 (1)粘膜下侵入腺は粘膜筋板の菲薄化した部分や, 血管ないしリンパ管の走行する間隙を経て, 囊胞

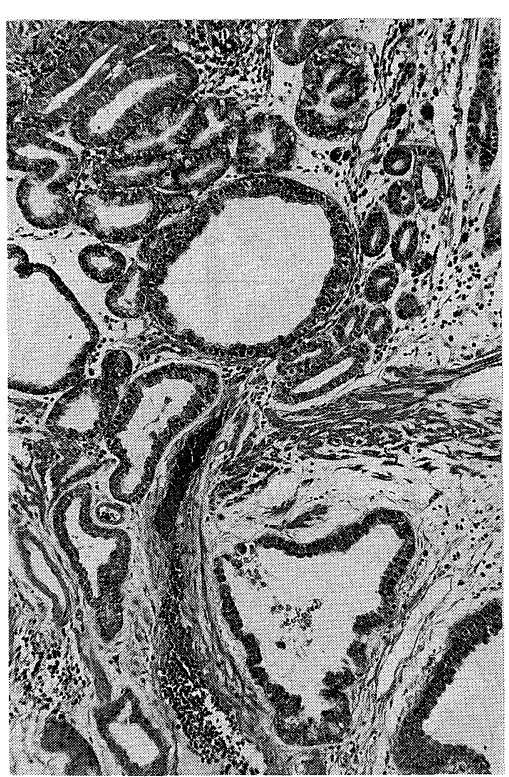

図 4 毛細血管が通過する粘膜筋板の間隙を経て, 腺管 が粘膜下層へ侵入していた（H.E. ×100)

腺との連続性を有していた（図 4). (2) 完全に孤 立化した囊胞腺もみられ，その腺腔には囊胞腺上 皮と連続性を有しつつ, 変性脱落していく上皮細 胞が豊富に存在しており, 偽重層化していた(図- 
$5 \mathrm{~b}$ ). (3) 囊胞腺汃表層へ向う腺管はやや狭小化 し, 局所性の炎症性細胞浸潤を伴って，一部では 破壊断裂していた（図 -5a）。(4)囊胞腺および粘膜 下侵入腺は, 腺窩上皮の形態を示す高円柱上皮と 腺上皮の形態を示す立方上皮の両要素加成り立っ ており，ほとんどの場合表層に近い部分は高円柱 上皮, 中間から深部は立方上皮により構成されて いた。一部の粘膜下侵入腺では，その関係が逆転 している場合も認められた。

\section{3. 吻合部以外の残胃の粘膜変化}

\section{A）縫合部}

縫合部は一般に初回手術時にペッツを使用して おり，また小弯に平行に切片を作製した症例もあ り, 縫合部については, 50例中 37 例の症例しか確 実に検索し得なかった。 その結果過形成性腺窝上 皮は，吻合部癌群の67\%（8例／12例）, 縫合部癌 群の67\%（4例 $/ 6$ 例）でみられたが，B- I 法対 照群，B-II 法対照群，胃体部癌群では，いずれも 認められなかった。囊胞腺の出現は吻合部癌群の $25 \%$ （3例 $/ 12$ 例), 縫合部癌群の $50 \%$ （3 例 $/ 6$ 例), B- I 法対照群の $10 \%$ （1 例 $/ 10$ 例）にみら
れたが，B-II 法対照群および胃体部癌群には認 められなかった。 また粘膜下侵入腺の出現は，吻 合部癌群の $42 \%$ （5例 $/ 12$ 例）, 縫合部癌群の $50 \%$ (3 例 $/ 6$ 例), 胃体部癌群の $33 \%$ (1 例 $/ 3$ 例), BI 法対照群の $10 \%$ （1例／10例）であった. BI 法対照群の 1 例は術後 3 週の症例で, 初回手術 の切除胃では, 多発性胃粘膜下囊腫の存在を認め た症例であった．B-II 法対照群には粘膜下侵入 腺の出現は認められなかった，従って全体では， 粘膜下侵入腺の出現は $27 \%$ （10例／37例）にみら れ，比較的術後年数の長い場合（10～32年，平均 2 0.4 年）に高頻度であった。しかし，上記検索方法 を行ったためてれらの所見を数値的に表現できな かった，腸上皮化生は，後述の如くほぼ全例に認 められ, 種々の程度の慢性萎縮性胃炎の像を呈し ていた。

B）その他の残胃粘膜

その他の残胃粘膜では，吻合部で目立った諸変 化（過形成性腺窩上皮・囊胞腺および粘膜下侵入 腺の出現）はほとんど認めなかったが，腸上皮化 生は吻合部と異なり，87\%（32例／37例）に認め

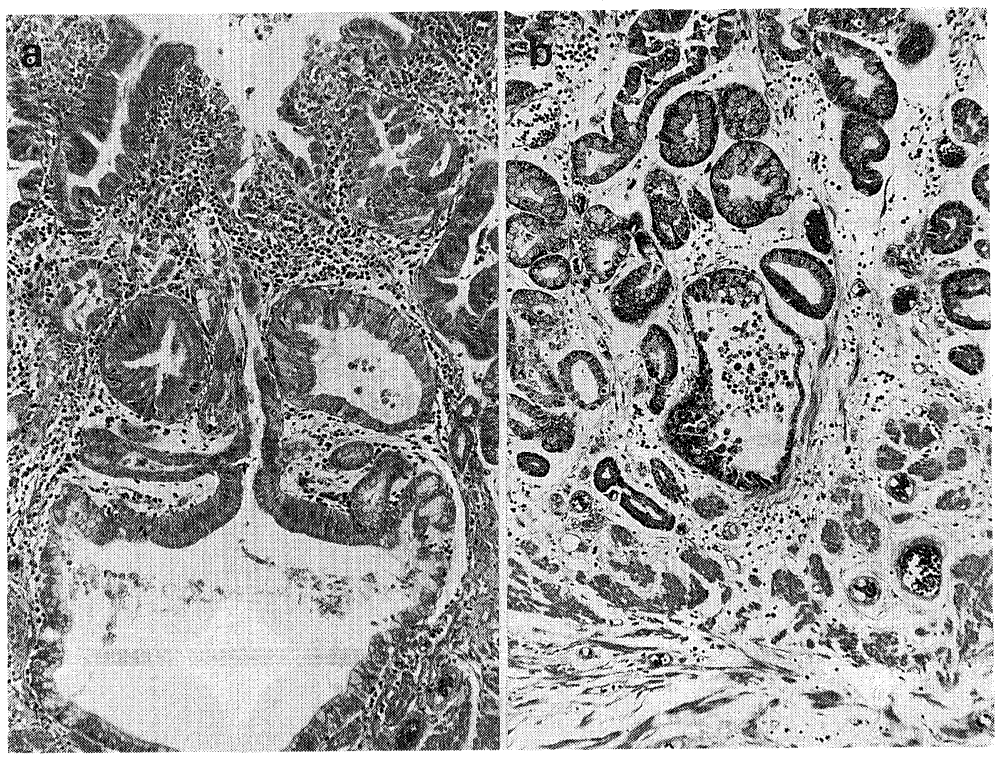

図 $5 \mathrm{a}$ 囊胞腺から表層へ向う腺管はやや狭小化し，炎症性細胞浸潤を伴い，一部破壊断裂していた。(H.E.×100)

図 $5 \mathrm{~b}$ 完全に孤立化した霊胞腺もみられ，その腺腔側では，偽重層化していた。（H.E．×40） 
表 $6 \mathrm{a}$ 腸上皮化生の拡がりの程度と術後年数

〈B-I method〉

\begin{tabular}{|c|c|c|c|c|c|c|c|c|}
\hline ( $\#$ ) & 3 & 2 & 1 & & & 1 & 1 & 1 \\
\hline (H) & 1 & 2 & & & 2 & 1 & 1 & 1 \\
\hline$(t)$ & 4 & 2 & 1 & & 1 & 4 & 3 & \\
\hline$(-)$ & $\begin{array}{c}1 \\
\text { case }\end{array}$ & & 1 & & 1 & 1 & 1 & \\
\hline 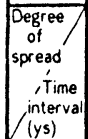 & $\begin{array}{c}0 \\
j \\
10\end{array}$ & $\begin{array}{l}11 \\
3 \\
20\end{array}$ & $\begin{array}{c}21 \\
5 \\
30\end{array}$ & 31 & $\begin{array}{c}0 \\
j \\
10\end{array}$ & $\begin{array}{l}11 \\
5 \\
20\end{array}$ & $\begin{array}{l}21 \\
30 \\
30\end{array}$ & 31 \\
\hline
\end{tabular}

表 $6 \mathrm{~b}$ 年齢と腸上皮化生の拡がりの程度との関係

〈B.I method〉

〈B-II method)

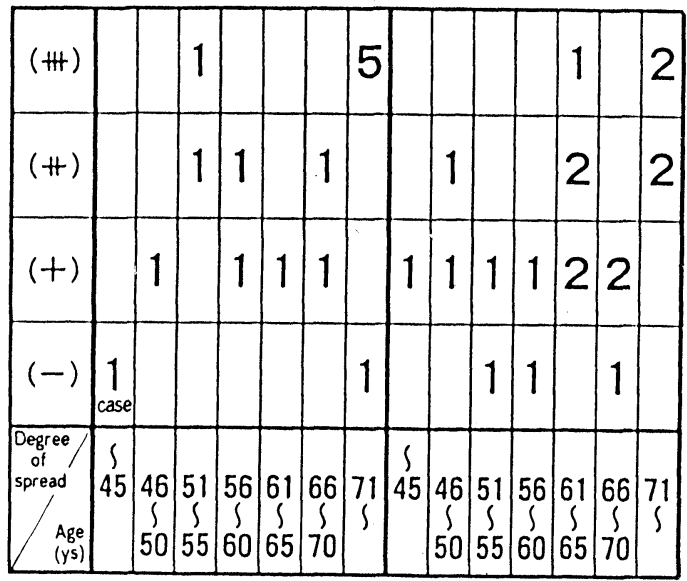

られ，いずれも小弯 (縫合部) 中心性にみられた。 腸上皮化生の程度をその広がりの程度により（一 )（曲）に分けると, 表-6 a, b 如くで, 残胃と いう環境が腸上皮化生の発現を促進するといった 結果は得られず, 通常胃に認められるように加齢 と共に増加しており, さらに B- I 法群と B- II 法群の間に有意な差はなかった。また，吻合部以 外の残胃に発生した癌周囲粘膜では, 分化型癌の $78 \%$ （7 病巣 $/ 9$ 病巣）に癌と隣接して腸上皮化 生が認められ，未分化型癌では25\%（1 病巣／4 病巣）と少なかった。

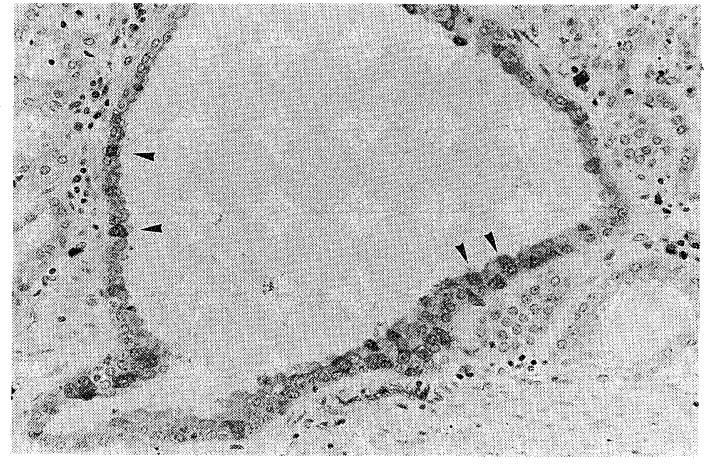

図 6 囊胞腺の一部の細胞は, その胞体が Lysozyme 染色で強陽性を呈した（矢印）。(Lysozyme $\times 200)$

\section{4. 組織化学的検索結果}

\section{A）吻合部の囊胞腺および粘膜下侵入腺}

吻合部の囊胞腺および粘膜下侵入腺は，高円柱 上皮および立方上皮により構成されており，一般 亿立方上皮の胞体内で Con-A（III）陽性を呈し， 一部 SC 陽性, lysozyme にも弱陽性となるが, 部 分的に lysozyme 強陽性細胞 (Paneth 細胞や macrophage と同程度）の分布を認めた（図-6). lysozyme 強陽性細胞の吻合部における出現と, 吻合部における様々な因子（囊胞腺の出現および その周長, 粘膜下侵入腺の出現およびその周長, 手術術式・術後年数 - 癌单の有無）との関係を見 いだすために，比較検討をした結果は表-7 a,b の 如くである。なお, lysozyme 強陽性細胞出現態 度については各症例ごとに, 平均 lysozyme 強陽 性細胞出現数（腺管内に見られた全 lysozyme 強 陽性細胞数／吻合部全割切片数）および平均 $1 \mathrm{y}-$ sozyme 強陽性細胞混入腺数 (lysozyme 強陽性細 胞を混入する全腺管数/吻合部全割切片数）のそ れぞれを, 囊胞腺・粘膜下侵入腺別に算出した数 值で表現し，いくつかの因子との関係を検索した。 その結果, lysozyme 強陽性細胞の出現数は, 囊 胞腺・粘膜下侵入腺それぞれ単独では, その大小, 術式の違い, 術後年数共に有意な関係を認めない が，囊胞腺内に関してのみ B-II 法吻合部癌群で 
表 $7 \mathrm{a}$ 各群における Lysozyme 強陽性細胞を含む囊胞腺および粘膜下侵入腺の出現数の比較

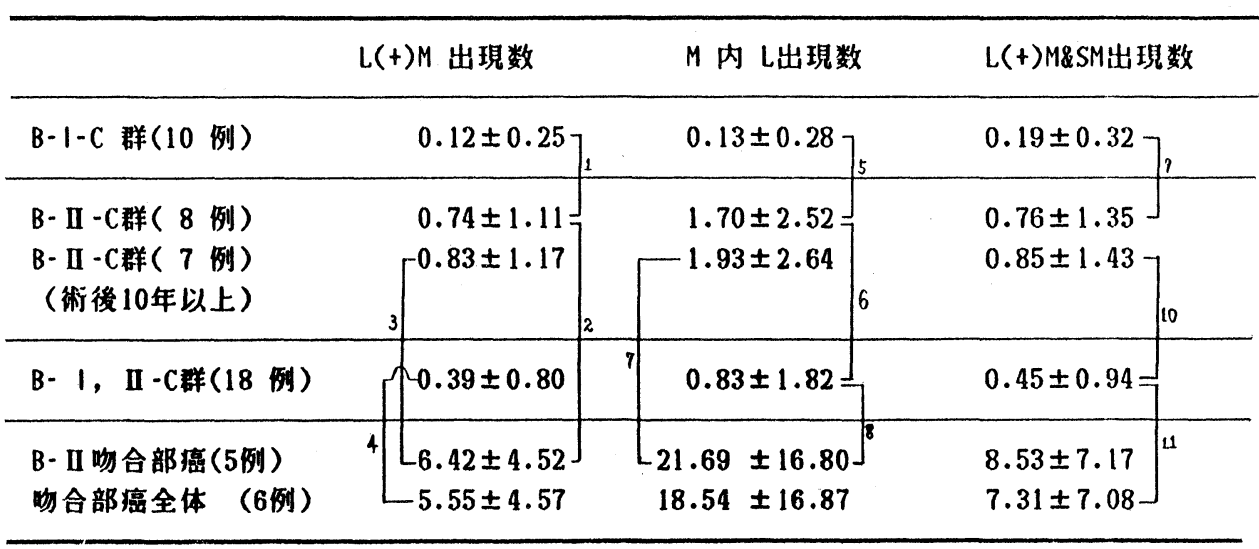

M: 霊胞腺 $\quad \mathrm{SM}$ : 粘膜下侵入腺 $\mathrm{L}(+)$ : リゾチーム強陽性細胞混入 $\quad \mathrm{L}$ : リゾチーム 強陽性細胞 $\quad 2,4: \mathrm{P}<0.05,3,6-8,10,11: \mathrm{P}<0.1, \quad 1,5,9$ : 差なし

表 7 b Lysozyme 強陽性細胞の出現の有無と囊胞腺及び粘膜下侵入腺の出現数, 外周長総和との関係

\begin{tabular}{lcc}
\hline & M+SM出現数 & M+SM周長和 \\
\hline しの出現した症例(9例) & $11.10 \pm 10.40$ \\
$\llcorner$ の出現しない症例(15 例) & $3.26 \pm 2.30$ & $8340.41 \pm 7840.80$ \\
\hline
\end{tabular}

$$
1,2: P<0.1
$$

最も多く出現し，また，囊胞腺 + 粘膜下侵入腺の 総数の多い症例に有意に目立った. 1ysozyme 強 陽性細胞混入腺の出現数は, 囊胞腺 - 粘膜下侵入 腺の各々では, 術式の違いと有意な関係がないが, 囊胞腺 + 粘膜下侵入腺の全体では, その腺管数の 多い症例, 腺管外周長の総和の長い症例に目立ち, それは, B-II 法吻合部癌群で最も多かった。

B）ヒト消化管における lysozyme 染色結果 lysozyme 強陽性細胞に注目し, その局在を知 るために胎児期 5 例 $(9,10,11,41,41$ 週 $)$, 新生 児 - 乳児期 6 例（ 0 日：4 例, 3 月 \& 9 月： 1 例ず つ), 幼児 - 学童期 5 例 $(2,2.5,6,8,11$ 歳 $)$ の それぞれの, 胃・小腸・大腸・胆囊と, さらに成 人胃 10 例, 多発性胃粘膜下囊腫 4 例に対して 1ysozyme 染色をし，以下の結果を得た。正常胃粘膜 上皮と考えた胃上皮では， lysozyme 強陽性細
胞は胎児から学童期を通じて通常認められなかっ たが，幽門腺・噴門腺および胃底腺の副細胞の腺 上皮は弱陽性を示した。しかし, 極めてまれに胃 底腺の副細胞に強陽性を示した. 正常小腸上皮で は Paneth 細胞に強陽性を示し, Brunner 腺は弱 陽性を呈した。正常大腸上皮では陽性部は認めら れなかった. 正常胆囊上皮では䅡部腺に陽性を示 した. 慢性胃炎では腸上皮化生のない場合, 幽門 腺の腺上皮は弱陽性, 腺䅡部に強陽性を呈するこ とが比較的よくみられた. 腸上皮化生のある場合 Paneth 細胞に強陽性を呈し, ごくまれに吸収上 皮も強陽性を呈した。 多発性胃粘膜下囊腫 4 例は, 全例に lysozyme 強陽性細胞の混入する粘膜下侵 入腺の存在を認めた. また前記の如く, 縫合部検 索可能であった残胃37例中10例に粘膜下侵入腺の 存在を認め, さらに10例中 9 例が lysozyme 染色 
可能であり，9例中 3 例 $(27 \%$, 吻合部癌 1 例, 縫合部癌 1 例, 初回手術の切除胃が多発性胃粘膜 下囊腫の残胃 1 例）に lysozyme 強陽性細胞の分 布を認めた。

\section{考察}

\section{1. 残胃吻合部の粘膜変化}

胃腸吻合部胃側の粘膜変化は，基本的には腺窩 上皮の過形成性変化, 固有腺の萎縮, 偽幽門腺化 生, 囊胞腺の出現であり, さらに粘膜下侵入腺を 認めることもあった。

A）過形成性病変と腸上皮化生

吻合部胃側の粘膜変化の最たるものは, Littler $ら^{71}$ (1972)により Gastritis cystica polyposa と命名された吻合部病変と一致し, 本邦では吻合 部ポリープ状肥厚性胃炎汭ともよばれている.

Littler らは, 乙の病変を可動性のある吻合部胃 粘膜が, 蠕動により腸側に脱出したものであると した。著者の検索では, 同病変に類似した粘膜変 化は術後年数の比較的長い B-II 法群で最も顕著 で，B-I 法群および Braun 吻合術を付加した B- II 法群では軽微であった. 腸内容液, 特に胆汁 の逆流の可能性の多い B-II 法群に, 過形成性腺 窩上皮の発現頻度の高かったととに注目した。近 年, 過形成性腺窩上皮に関しては, 左野ら ${ }^{91}$, Kon do $ら^{10)}$, Kobori ら ${ }^{111}$ がラット胃での実験よりそ れを裏付ける所見を得ており, 過形成性腺窩上皮 の組織発生と, 吻合後の腸内容液特に胆汁の逆流 現象と, 密接な関係があるであろうとの結論に達

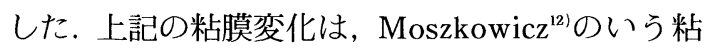
膜改築の一現象であると考えられるが, 腸上皮化 生はむしろ B-II 法群では極めて少なく，4\%弱 ( 1 例 $/ 27$ 例)の症例に認めたのみであり, 上記病 変の軽度な B- I 法群で $58 \%(11$ 例 / 19例 $)$ みら れたととと対照的であった. Moszkowicz は,「腸 上皮化生は, 胃粘膜の障害が広汎で, かつ何度も 同じ場所に繰り返された際に, 粘膜の再生が不完 全となり,さらに再生能が低下した際に出現する. しかし一方では, 再生能力の低下に対して, 他の
部の胃粘膜で過鄱な再生がなされる」としている が，粘膜の最たる損傷部である B- II 法群の吻合 部で，腸上皮化生がほとんど認められないことの 本質的な原因の解明は，腸上皮化生そのものにお ける今後の研究結果を待たなければならない.

B）囊胞腺および粘膜下侵入腺の発生原因とその 存在意義

吻合部に存在する囊胞腺は, 固有腺, 特に偽幽 門腺および胃底腺の囊胞状に拡張した腺管であり， その出現数は Braun 吻合術を付加していない BII 法群に限り, 術後年数とほぼ相関して増加す る傾向にあった，連続切片標本作成にて，囊胞腺 から表層へ向う腺管の一部は, 局所性の炎症性細 胞浸潤を伴い破壊断裂し，狭小化していた。また 完全に孤立化し，変性脱落した上皮が腺腔内に既 存の腺上皮と一部連続性を有しつつ, 豊富に存在 しているような囊胞腺をも認められた。吻合部に みられる囊胞腺に関して, 他の研究ではほとんど 詳細な検索をみないが，岡田 ${ }^{13}$ は, ENNG（N-ethyl-N'-nitro-N-nitroso-guanidine)を投与した後 auto-radiography を用いて, ラット胃粘膜の萎 縮性変化について検索しているが，その際認めら れる囊胞状拡張腺管の下部で長期にわたり, 標識 細胞の存在をみたと述べている. Ramzi ${ }^{14)} は$, aut oradiography を用いてヒト残胃の胃底腺領域で は，増殖帯が拡大していることを示した．以上の ことと囊胞腺の出現数が，Braun 吻合を付加して いない B-II 法対照群の場合, 術後年数と共に増 加する傾向にあり, 囊胞腺の出現分布が吻合部か ら口側 $1 \mathrm{~cm}$ 以内にピークを有していたてとより， 囊胞腺は, 胆汁を主体とした腸内容液の逆流を基 盤とした組織破壞の, 修復の過程で発生するもの と考えられ, さらに吻合部の胃粘膜の腺頝部増殖 分裂帯は，たえず活発な細胞分裂を行っており， その増殖帯の長さも腺䅡部で上下方向に拡大し, 囊胞腺内一も延長していると考元られた．粘膜下 侵入腺は，その分布が囊胞腺の場合とほぼ一致し， しかも粘膜固有層内の囊胞腺と連続性を有してお り，その出現は囊胞腺の出現と有意な関係があり, B- II 法対照群に多かった. 従って粘膜下侵入腺は, 
囊胞腺が腺管の存在する場としての方向性」を 失った形として出現するものと考えられるが, 囊 胞腺とは異なり, B- II 法群においても術後年数 と関係を示さず, しかも, B-I 法群の吻合部や縫 合部にもみられることがあるため, 粘膜筋板の脆 弱性, あるいは Griffel ら ${ }^{15)}$ が述べているように 手術操作 (その修復も含めて) そのものも, その 出現に影響を与えている可能性も否定できない.

以上より, 虽胞腺および粘膜下侵入腺が顕著に みられる吻合部では, 同部の腺頚部増殖分裂帯で, 活発な細胞分裂が行なわれているものと考えられ た。

\section{2. 残胃癌の肉眼的および組織学的特徵}

佐野の分類にならって, 残胃癌の肉眼型を隆起 型（II b を含む）と潰瘍型に分類し, 自験残胃癌 2 5 例29病单を再検討し, 第38回胃癌研究会での残 胃の癌の全国アンケート ${ }^{16)}$ (初回病変良性疾患の 残胃の癌）および国立ガンセンター（佐野）での 通常胃癌とを比較すると表-8の如くである. 残胃 癌 (自験例も含めて) は, 通常胃癌に比べて, 早 期癌の場合隆起型が多い傾向にあり, 進行癌の場 合潰瘍型が多い傾向にあった。また組織学的には, 残胃癌は, 早期癌の場合分化型が多い傾向にあり, 進行癌の場合は, 分化型がやや少ない傾向にある. しかし, これらの所見は II c 等の早期癌の見落し の可能性もあるので, 必ずしも上記の傾向が真実 とはいい切れない, 一方, 一般にまれとされる隆 起型の未分化型癌が 2 病巣見られた. そのうち 1 例は II b で，もう 1 例は，過形成性腺窩上皮を背 景とした Borr.1+ II c であった。

\section{Lysozyme 強陽性細胞の意味}

堤ら ${ }^{17} は$, 以前より種々な角度から lysozyme 染色を行ってきているが, 正常に近い胃粘膜上皮 では，腺窩上皮と幽門腺上皮とを分かつ増殖帯を 中心とした領域に局在して陽性を示すのが特徵的 で, 炎症性変化などにより深部腺窩上皮や，幽門 腺上皮が応性変化をとげると, 同部にも強く発 現されてくる, と述べており,また, lysozyme が 胃粘膜においては, 増殖能に富む細胞のマーカー になるとしている. Lewellyn \& Stanley ${ }^{18}$ は,
表 8 残胃癌の肉眼的, 組織学的特徵

\begin{tabular}{|c|c|c|c|c|c|c|}
\hline & \multicolumn{2}{|c|}{ 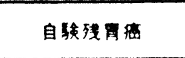 } & \multicolumn{2}{|c|}{ 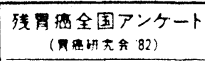 } & \multicolumn{2}{|c|}{ 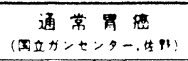 } \\
\hline & 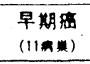 & 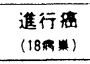 & 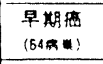 & 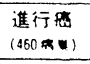 & 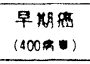 & 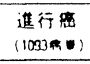 \\
\hline $\begin{array}{l}\text { 櫘 } \\
\text { (\%) }\end{array}$ & 72.7 & 16.7 & 51.6 & 9.8 & 30.0 & 40.0 \\
\hline 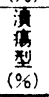 & 27.3 & 83.3 & 48.4 & 90.2 & 70.0 & 60.0 \\
\hline 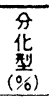 & 72.7 & 33.3 & 57.1 & 41.0 & 47.5 & 49.2 \\
\hline 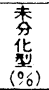 & 27.3 & 66.7 & 42.9 & 59.0 & 52.5 & 50.8 \\
\hline
\end{tabular}

lysozyme 強陽性細胞がラット小腸において, 胎 仔期における小腸の発生過程上, Paneth 細胞の 出現以前より存在し, Paneth 細胞の出現後は Paneth 細胞に lysozyme が局在することを示し ている，著者の検索によれば，正常胃粘膜上皮に は lysozyme 強陽性細胞は存在しない.しかし， 慢性胃炎の状態では, 腸上皮化生粘膜の Paneth 細胞（ごくまれに吸収細胞も）は強陽性を呈し, 腸上皮化生のない場合は, 腺䅡部に強陽性を示す こともあった。 また, lysozyme 強陽性細胞の出 現数は, 吻合部全体の拡張腺管 (囊胞腺 + 粘膜下 侵入腺）の出現数および外周長の総和と有意に関 係が深く，いずれも，B II 法吻合部癌群に最も多 かった，以上を考慮に入れると, lysozyme 強陽 性細胞は胃粘膜上皮には本来存在しない細胞であ り, 腺䅡部の活発な細胞分裂の中で（実際には実 験以外には証明しきれないと考えられる), 粘膜 環境の変化に対して出現した細胞, あるいは分化 方向の混乱の結果生じた細胞と考えられるが，一 方では, 形態学的に Paneth 細胞と認識できない 原始的 Paneth 細胞である可能性も考えられる. いずれにしても, ての lysozyme 強陽性細胞が, 増殖分裂帯から生じた突然変異の産物であること に間違いないものと考えられる。

4. 残胃癌の組織発生

胃癌組織発生に関して様々な論議がなされてき たが, 現在では『分化型癌は, 腸上皮化生と密接 


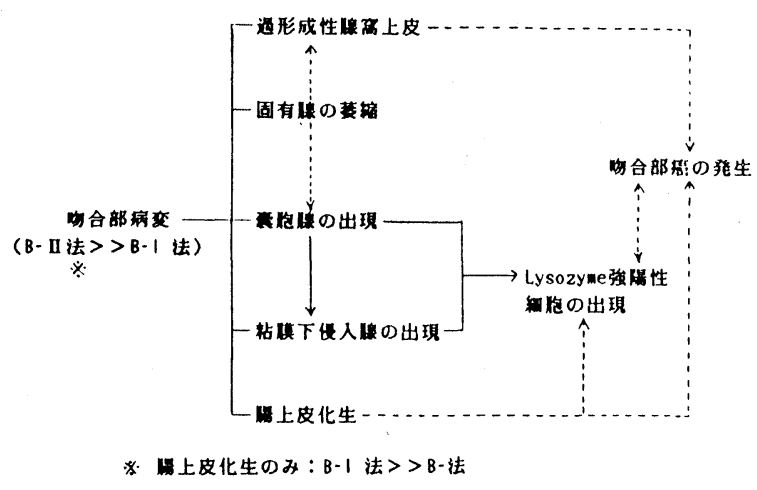

図 7 残胃吻合部の胃粘膜変化の相互関係および吻合部 癌との関係

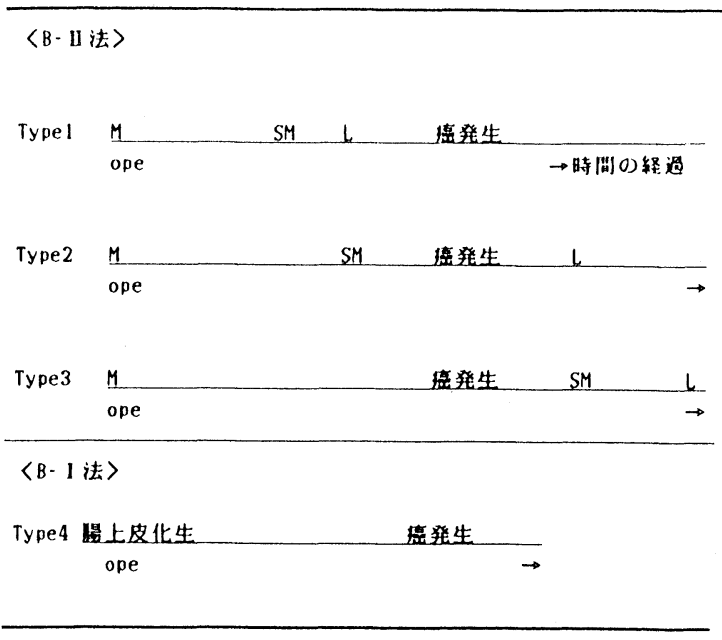

図 8 残胃吻合部癌発生のプロセスの模式図

$\mathrm{M}$ : 囊胞腺の出現および増加

$\mathrm{SM}$ : 粘膜下侵入腺の出現

L：リゾチーム強陽性細胞の顕著な出現

な関係を持ちつつ発生するが，未分化型癌は正常 に近い胃固有腺の腺䅡部より発生する』との考え が一般的であり, Taki \& Kuwabara ${ }^{19)} も ， 13$ 例 (53病巣) の微小癌の詳細な検索より同様の見解 を示している. 著者の検索では, 吻合部以外の残 胃粘膜において腸上皮化生は，87\%（32例／37例） の症例にみられ, しかも B- I 法群および B- II 法 群の高齢者に顕著な広がりをみた。このような粘 膜変化を背景にして, 吻合部癌よりも術後年数に
して10年近く早くに, その他の残胃癌の発生をみ, さらに, 胃体部癌の場合は表-1 a, bの如く, その8 3\%（B- I 法群: 2 病巣 $/ 3$ 病巣, B- II 法群： 3 病 巣 $/ 3$ 病巣）が分化型を示していた. 一方, 縫合 部癌は57\%（B- I 法群：3病巣 $/ 6$ 病巣, B- II 法 群: 1 病巣 $/ 1$ 病巣）が分化型を示した. 胃体部癌 の場合は顕著な腸上皮化生を背景としており，そ の発生は, 上記仮説と矛盾しえないものと解され る. しかし, 縫合部癌の場合はその背景に腸上皮 化生がよくみられる一方で, 過形成性腺窩上皮・ 囊胞腺および粘膜下侵入腺が, 吻合部癌の場合程 でないにしても高頻度にみられ, 残胃という特殊 な環境の変化を背景に発生する可能性が示唆され るが, 今回の検索方法からはこれ以上の推察は難 しかった.

吻合部から発生する分化型癌は, 従来から腸上 皮化生の関与が少ないてとから注目されてきた。

著者の検索によれば, 吻合部分化型癌 7 病巣の周 囲において，B-I 法の 1 病巣を除いた B-II 法 の 6 病巣では, 腸上皮化生の出現は極めてまれで あった. Konjetzny ${ }^{20)}$, 福地ら ${ }^{211} は$, 過形成性腺窩 上皮からの癌化を推定している.一方, 藤田 ${ }^{22}$ は, 胃癌組織発生論の中で associative type の腫瘍 細胞（分化型癌細胞）が, 非異型細胞の流れから 免れて定着し, 初期生長をするためには粘膜深部 に腺の断片が埋没する必要があると述べ，ヒトで は腸上皮化生の進行が最も頻度が高いとし, 胃腸 吻合部の囊胞腺もその一つであるとも指摘してい る.

吻合部に認められた様々な粘膜変化を個々の因 子に分け, 互いの関係を統計処理した結果, 得ら れた相互関係は図-7 の如くである. 癌が全く偶発 的に出現するものでない限り, この相互関係は吻 合部癌発生のメカニズムの主要をなすものと考え られるが, これをもとに仮想される癌発生のプロ セスは, 図-8の如く4つの型式が導かれる. B- I 法吻合部癌に関しては 1 例のみであったが, Type 4 が仮想され, 残胃胃体部癌と同様に, 残胃とい う特殊な環境の変化を背景として発生する可能性 は少ないと考えられた. B- II 法吻合部癌の発生 
においては, Type 1, 2, 3 のいずれであるのか, あるいはすべてであるのかは決定し得なかった。 しかしながら, 吻合部癌の存在と lysozyme 強陽 性細胞の出現は, 密接な関係を有すこと（縫合部 癌の場合は, その縫合部には 7 例中 1 例のみにし か, lysozyme 強陽性細胞は出現しなかった), しかも, lysozyme 強陽性細胞の出現と胃粘膜上 皮の増殖性変化は, 深い関係を持つ可能性がある ことが判明し，今後さらに多方面からの検討が必 要であると考えられた。

\section{結論}

残胃癌背景粘膜および組織発生を知る目的で, 自験残胃癌 25 例（29癌病巣）を含め計50例の残胃 を中心に病理組織学的に検索し, 次の結論を得た。 1. 残胃吻合部胃側の粘膜変化は, 腺窩上皮の過形 成, 固有腺の萎縮, 胃底腺の偽幽門腺化生, 囊胞 腺および粘膜下侵入腺の出現を主体とし, 術後年 数の長い B- II 法群により顕著で, 腸内容液逆流 を基盤とする組織破壞に対する過剰な修復の結果, 生ずるものと考えられた。

2. 腸上皮化生は, 上記粘膜変化の顕著な B- II 法 群の吻合部では, 極めて稀にしか認めなかったが, B- I 法群の吻合部および吻合部から離れた残胃部 （B-I 法群および B-II 法群）では比較的高頻度 に認められた。

3. 残胃胃体部癌および B- I 法吻合部癌は, 残胃 という特殊な粘膜変化を背景として発生するとは 考えられなかった。

4. 残胃縫合部癌は, 過形成性腺窩上皮・囊胞腺お よび粘膜下侵入腺が, 吻合部癌の場合程でないに しても高頻度にみられ, 残胃という特殊な環境を 背景に発生する可能性が示唆されたが，今回の検 索方法からはこれ以上の推察は難しかった。

5. 吻合部癌周囲に顕著にみられた囊胞腺および 粘膜下侵入腺の腺上皮には，本来胃粘膜上皮には 存在しない lysozyme 強陽性細胞の分布を比較的 顕著に認め, このような囊胞腺および粘膜下侵入 腺の出現を背景とした lysozyme 強陽性細胞の出
現と吻合部癌の存在は, 因果関係があるものと考 えられた。

本論文の要旨は, 第73, 第74回日本病理学会総会 $(19$ 84，1985）および第26回日本組織細胞化学会総会 (1985) において発表した．本研究を遂行するにあたり，で懇篤 なるで指導とで校閲を賜った順天堂大学医学部第一病理 学教室福田芳郎教授に厚くお礼申し上げます．また，終 始直接で指導頂いた桑原紀之助教授, ならびに滝 和博 講師に深く感謝致します. また, 病理学教室員ならびに 技術員各位ので協力に心から感謝致します。

\section{文献}

1) 白壁彦夫, 他: 残胃癌のX線診断. 臨放, 27: 593 599, 1982

2) 城所 仂, 他: 残胃の癌と「残胃癌」. 消化器外科, 8: $31 \sim 35,1985$

3）胃癌研究会編：胃癌取り扱い規約. 第10版, 金原出 版, 1979

4）加治文也, 他: 残胃吻合部に発生した多発性早期胃 癌の 1 例. Progress of Digestive Endoscopy, 19: $205 \sim 208,1981$

5) 佐野量造: 胃疾患の臨床病理. 1 7, 第 1 版. 東京, 医学書院, 1974

6) 平福一郎: 慢性胃炎の病理組織像. 胃と腸, 2: 125 7 1264, 1967

7) Littler E R, et al: Gastritis cystica polyposa. Cancer 29: 205 209, 1972

8) 古賀 淳, 他: 胃腸吻合部に見られるポリープ状病 変. 福岡医誌, 67: 285 296, 1976

9）左野千秋, 他: 胃切除術式の残胃癌発生プロモーショ ンに及ぼす影響に関する実験。日消外会誌，17：2130 $\sim 2136,1984$

$10)$ Kondo K, et al.: The influence of gastrojejunal anastomosis on gastric carcinogenesis in rats. Gann 75: 362 369, 1984

11) Kobori O, et al.: Enhancing effect of sodium taurocholate on N-methyl-N'-nitro-N-nitrosoguanidine-induced stomach tumorigenesis in rats. Gann 75: 651 654, 1984

12 ) Moszkowicz L: Regeneration u. Krebsbildung in der Magenschleimhaut. Arch. Klin. Chir. Langenbecks 132, 1924 
13）岡田勝弘: ラット実験胃癌背景粘膜の構築変化に関 する定量形態学的研究. 京府医大誌, 92: 453 473,1 983

14) Ramzi $T$, et al.: Epithelial proliferation in human fundic mucosa after antrectomy and vagotomy. Gastro-enterol. 79: 807〜811, 1980

15) Griffel B, et al.: Multiple polypoid cystic gastritis in old gastroenteric stoma. Arch. Pathol. 97: $316 \sim 318,1974$

16）城所 仂: 残胃の癌切除例の遠隔成績. J. J pn. Soc. Cancer Ther. 17: 2029 2034, 1982

17）堤寛, 他: 腸上皮化生と免疫. 最新医学, 37: $1140 \sim 1151,1982$

18) Lewellyn J, et al.: Differentiation of Paneth cells in neonatal rat intestine using immunocytochemistry for the localization of lysozyme. Abstracts of the histochemical society. 616, 1976

19) Taki K, et al.: Studies on histogenesis of the gastric carcinoma using minute cancers. Path.Res.Pract. 172: $176 \sim 190,1980$

20) Konjetzny GE: 胃癌, 第 1 版, 山田 喬, 他訳, 学際企画, 東京, 1981

21）福地創太郎, 他: 十二指腸潰瘍で胃切除後 19 年目に 診断された残胃吻合部早期胃癌（II a ）の 1 例. 胃と 腸, 17: 1329 1332, 1982

22）藤田晢也：細胞動態からみた胃癌の発生と進展．日 病会誌, 70: $23 \sim 54,1981$

\section{Original Paper}

\section{Summary}

\section{Pathological Studies on the Histogenesis of Carcinoma of the Gastric Remnant}

In order to study the background and histogenesis of carcinoma of the gastric remnant, 50 patients with gastric remnants including 25 with carcinoma of the gastric remnant were examined pathologically. Carcinoma of the gastric remnant, except for stomal carcinoma, was present in the gastric remnant with diffuse intestinal metaplasia and frequently showed well-differenciated type adenocarcinoma. Stomal carcinoma coexisted with stomal gastritis. In the area of stomal gastritis, hyperplastic foveolar epithelium, atrophy of the gastric glands, and cystic dilatation of mucosal and submucosal glands were noted. Mucosal cystic and submucosal glands were seen more frequently in the stomal area of B-II control cases than in those with B- I. The epithelial cells of mucosal cystic glands and submucosal glands were partially stained by concanavalin-A (III), secretory components, and lysozyme. The appearance of strongly lysozyme positive cells in the mucosal cystic glandular epithelium was more frequently found in the control cases with B- II than in those with B- I and more frequently in stomal carcinoma than in the control cases with B-II. It is emphasized that there is a relation between the presence of stomal carcinoma and the appearance of strongly lysozyme positive cells in the epithlium.

Key words: carcinoma of gastric remnant, stomal carcinoma, stomal gastritis, intestinal metaplasia, lysozyme

R yo WADA, M.D.

Department of Pathology (I), Juntendo University School of Medicine 